resulting corneal ulceration. It is probable that an overwhelming number of these were affected by trachoma.

The remarkably high percentage of primary glaucoma among the blind is noteworthy, being more than 6 per cent.

There has been a rise in blindness since the year 1928, which is correlated with a cycle of years with a rainfall much below the average. In Palestine, as elsewhere, dry years are associated with increased severity in the seasonal epidemics of acute conjunctivitis, by far the commonest cause of blindness.

A praiseworthy effort is being made to teach Arab girls some elementary ocular hygiene. However, when one has to remember that in many distant villages water is rationed with eye-dropper economy it is difficult to envisage any rapid advance.

It is of importance to note that approximately $i 4$ per cent. of the patients were of the Moslem faith.

\title{
OBITUARY
}

\section{JULES GONIN}

Professor Jules Gonin, whose death on June 11 was briefly noted in our last number, was born at Lausanne on August 10, 1870. On his father's side he was descended from a Protestant family of refugees from the valleys of Piedmont who had settled in the canton of Vaud. On his mother's side he was connected with Berne.

His early years of study were passed at the College Galliard and later in the Cantonal Gymnasium. He next entered the faculty of Science of the old Academy, then the faculty of Medicine at Lausanne, and later that at Berne.

His first introduction to ophthalmology occurred while still an undergraduate when he served as locum tenens to the resident officer at the Hôpital de l'Asile des Aveugles, where, in 1896, he became the resident officer. In 1899, after a tour of study in foreign countries, he became chief assistant, and in 1901 second AssociateSurgeon.

In 1918 he became Surgeon in Charge of the Asile des Aveugles, and in 1920, on the death of Professor Eperon, Professor of Ophthalmology in the University.

Although ophthalmology was his life's work, Professor Gonin had many other interests. He was an active member of the Alpine Club and made many ascents, preferring glaciers to rocks. He had a profound knowledge of every corner of Switzerland. He was a great traveller and had explored the whole of Europe as well as 
Palestine and Egypt. He had the gift of languages : not only was he an adept in all the various dialects of Switzerland but could speak fluently in many other languages including Spanish, Serbian, Modern Greek and Arabic. Even after he had passed middle life he learned new languages. He spoke of this knowledge in terms of the gramophone, saying, that when about to speak English he wouid put on his English gramophone record.

He was one of the founders of the Swiss Ophthalmological Society in 1908, and attended all the meetings with the exception of the last which took place fifteen days before his death.

In politics he was a liberal, and following his father, he was a fervent supporter of proportional representation.

Coming now. to his scientific work, without doubt the name of Gonin will always be associated with the cure of detachment of the retina, but his serious work on this subject did not begin until 1918.

Before this date, his communications were numbered by the dozen. He gained his laureate at the University by his work on the development of the wings of the butterfly in the chrysalis. The butterfly was always his favourite, and his consulting room was decorated by actual specimens pinned to the ceilings and walls.

His thesis for the Doctorate was on the regeneration of the crystalline lens.

His aptitude for drawing, and the need he felt for elaborate notetaking certainly has made for much of the accuracy which characterized his works.

In 1898 he began his ophthalmological publications : at first thev had an anatomical and pathological character with an examination of macroscopical and microscopical specimens, or dealt with the bacteriology of ocular affections. Later on, clinical observations played a greater rôle, one group concerning the annular scotoma of retinitis pigmentosa in which he showed that concentric diminution of the field of vision is often only annular, and that when it is really concentric it is but the terminal stage of an annular scotoma which has reached the periphery.

In 1900 Professor Dufour was entrusted with the re-writing of the large chapter ('Diseases of the Retina and Optic Nerve') for the French Encyclopaedia of Ophthalmology, and he collaborated with his devoted pupil Gonin. Thus it happened that Gonin had to take notice of all that had been said or written on diseases of the retina. It was this work that gave birth to his ideas on the causes of detachment of the retina, its pathology, the importance of rents and so on.

Gonin also wrote the chapter on amaurosis and amblyopia for the Encyclopaedia.

The first work of Gonin on detachment of the retina appeared 
in 1908, but it was in 1918 that a paper 'The Anatomical Causes of Detachment of the Retina' conducted oculists to the point they have reached to-day. Thirty-eight publications of greater or less importance were made by Gonin on this subject between 1918 and 1934, and in 1934 appeared his large book 'Detachment of the Retina' which crowned his work.

It is necessary to go back seventy years in the history of ophthalmology, to the introduction by von Graefe of the curative value $\vec{a}$ of iridectomy for glaucoma, to meet with a discovery comparable with that of Gonin's.

Oculists from all parts of the world visited Lausanne to be welcomed by this charming and vivacious man who spent much? of his time in explaining to all his views, and if opportunity $\overrightarrow{0}$ arose, showing them the details of the operation he had devised.

Professor Gonin, besides being a member of the Swiss Ophthalmological Society, was also a member of the French Society and that of Heidelberg.

In 1929 he was awarded the Marcel Benoist prize, and in 1934 he visited Glasgow to give the William Mackenzie Memorial lecture, and to receive the Mackenzie Medal.

\section{NOTES}

Death

WE regret to record the death of Reginald $\stackrel{\circ}{\circ}$ Arthur Yeld, M.A., M.D.Cantab., of Edgewood, British Columbia, on April 3, 1935. Dr. Yeld was born in London and educated at Cambridge University and St. Bartholomew's Hospital, where he acted as ophthalmic house surgeon. He began practice in Hampstead but migrated to British Columbia about 20 years ago.. Always interested in ophthalmology, Dr. Yeld was well known over; a wide area for his work on refraction. In 1932 he published. privately a thesis on "Accommodation in the Human Eye," which was reviewed in our columns in January last.

\section{Knapp}

Knapp THIs lecture was delivered before the ophthalMemorial Lecture mological section of the American Medicalo Association on June 12, by Mr. Leslie Paton, who has been elected 0 an hon. member of the Association as well as of the Association for Research in Ophthalmology.

The subject of the lecture was "Papilloedema and Optic Neuritis? -a Retrospect." At the conclusion Mr. Paton was presented with the Knapp Memorial Prize. 